In future the necessity of development of model of forming of creative abilities of junior pupils arises by means of theatrical art.

Key words: personality, creative abilities, intellect, activity, cognitive activity, junior pupils, social environment, theatrical art.

УДК 796.012.412.4:613.25-055.2

Людмила Прокопова

Сумський державний педагогічний

університет імені А. С. Макаренка

ORCID ID 0000-0002-3731-0729

Світлана Гвоздецька

Сумський державний педагогічний

університет імені А. С. Макаренка ORCID ID 0000-0002-7744-7471

Тетяна Гриб

Сумський національний аграрний університет

ORCID ID 0000-0001-8957-8244

Тетяна Клименченко

Сумський національний аграрний університет

ORCID ID 0000-0002-7835-6432

DOI 10.24139/2312-5993/2019.05/246-256

\title{
СКАНДИНАВСЬКА ХОДЬБА ЯК ЗАСІБ ЗНИЖЕННЯ НАДМІРНОЇ МАСИ ТІЛА ЖІНОК ДРУГОГО ПЕРІОДУ ЗРІЛОГО ВІКУ В УМОВАХ САМОСТІЙНИХ ЗАНЯТЬ
}

Вивчено вплив скандинавської ходьби на зниження надмірної маси тіла жінок 56-60 років. Визначено зміни рівня фізичного стану жінок, які займаються скандинавською ходьбою. Розроблено та експериментально перевірено методику зниження надмірної маси тіла жінок другого періоду зрілого віку в умовах самостійних занять.

Mета роботи: обгрунтування та доведення ефективності експериментальної методики зниження надмірної маси тіла жінок другого періоду зрілого віку в умовах самостійних занять.

Методологія. Методологічну основу дослідження становлять принципи теорії наукового пізнання, концептуальні положення психології, педагогіки, медицини, у яких вироблено найважливіші принципи аналізу соціально-психологічних та педагогічних явищ, теорія тренувального процесу.

Наукова новизна. Гіпотеза дослідження полягає в тому, що поєднане застосування аеробних, силових, швидкісних, інтервальних вправ приведе до більш вираженої корекції форм тіла у жінок другого періоду зрілого віку в умовах самостійних занять.

Висновки. У результаті аналізу літературних джерел було встановлено, що надмірна маса тіла є однією з основних проблем жінок сучасності. Нагальним завданням стає пошук засобів схуднення та запобігання подальшого набору маси тіла. В експериментальній групі була досягнута позитивна динаміка зменшення 
маси тіла, об'єму талії, підвищення рівня фізичного стану. у результаті дослідження встановлено, що поєднане застосування аеробних, силових, швидкісних, інтервальних вправ, які є складовими експериментальної методики, приводить до зниження маси тіла жінок другого періоду зрілого віку в умовах самостійних занять.

Ключові слова: скандинавська ходьба, надмірна маса тіла, фізичний стан, експериментальна методика.

Постановка проблеми. Надмірна маса тіла - це велика і серйозна проблема сучасності. В Україні, за найскромнішими підрахунками, від надмірної маси страждає кожна четверта жінка і кожен шостий чоловік. Загалом від ожиріння страждає близько 15 \% населення нашої країни. Жінки більш схильні до ожиріння, ніж чоловіки, лікарі це пов'язують з особливостями жіночого організму (Мировая статистика здравоохранения 2014 г.).

Найчастіше причинами ожиріння в Україні $\epsilon$ неправильне харчування, недостатнє фізичне навантаження, що призводить до низького рівня фізичної підготовленості і, як наслідок, порушення в роботі нервової та ендокринної систем організму. Причинами розвитку ожиріння також вважаються генетичні фактори. І якщо на генетику ми не можемо впливати, то на останні чинники - так. Все це зумовлює актуальність і доцільність наукового пошуку ефективних засобів, які сприяють зниженню маси тіла (Рибалко та ін., 2016).

Скандинавська ходьба з палицями - не панацея від надмірної маси тіла, однак, це ефективний засіб профілактики та покращення фізичного стану. Те, як прискорити процес спалювання жиру, і чому скандинавська ходьба є кориснішою за інші види рухової активності, ми маємо довести.

Аналіз актуальних досліджень. Проблема зниження надмірної маси тіла у процесі занять скандинавською ходьбою досліджувалася в роботах вітчизняних та зарубіжних авторів. Так, на думку Ю. А. Копилова (Копылов, 2014), при скандинавській ходьбі 90 \% м'язів тіла беруть участь у роботі. За рахунок цього витрачається калорій на 40-50 \% більше, ніж при звичайній ходьбі. Автор також наголошує, що 35 \% тих, хто займаються скандинавською ходьбою з палицями, є жінки першого і другого періодів зрілого віку.

C. С. Чернов і А. А. Стрельцов (Чернов та Стрельцов, 2011) стверджують, що для зниження маси тіла, особливо підвищення функціональних можливостей серцево-судинної і дихальної систем, перевага надається ходьбі у швидкому темпі, ніж бігу. Автори також наголошують, що ефективне згорання жирових відкладень відбувається при частоті серцевих скорочень 120-170 ударів за хвилину.

С. М. Футорний (Футорний, 2015) доводить, що скандинавська ходьба відноситься до ефективних циклічних вправ аеробної 
спрямованості і може бути застосована як для збільшення обсягу рухової активності, так і для корекції факторів ризику розвитку серцево-судинних захворювань, збільшення функцій систем дихання і кровообігу, опорнорухового апарату, обміну речовин, що в цілому впливає на зниження ваги.

Д. О. Микиша (Микиша, 2013) у своїх наукових дослідженнях доводить, що скандинавська ходьба - доступний всім вид спорту для занять на відкритому повітрі. Цей вид рухової активності особливо ефективний як засіб рекреаційних занять для осіб різного віку, у тому числі і з низьким рівнем здоров'я.

О. І. Павловська та І. І. Васяніна (2018) розробили експериментальну методику оздоровчих занять скандинавською ходьбою для жінок старше 50 років, які віднесені до першої і другої груп здоров'я з урахуванням методики лікувальної фізичної культури при соматичних захворюваннях і які мають надмірну масу тіла.

Проблема зниження надмірної ваги жінок другого періоду зрілого віку засобами скандинавської ходьби з палицями обумовлена недостатнім iї висвітленням у науково-педагогічній, психологічній та медичній літературі; низьким рівнем сформованості знань і культури рухів для самостійних занять; недостатньою відпрацьованістю засобів, методів і форм тренування, обсягів навантаження.

Мета статті - обґрунтування та доведення ефективності експериментальної методики зниження надмірної маси тіла жінок другого періоду зрілого віку в умовах самостійних занять.

Методологія. Методологічну основу дослідження становлять принципи теорії наукового пізнання, концептуальні положення психології, педагогіки, медицини, у яких вироблено найважливіші принципи аналізу соціально-психологічних та педагогічних явищ, теорія тренувального процесу.

Для реалізації поставленої мети та рішення завдань були використані такі методи дослідження: теоретичний аналіз і узагальнення літературних джерел, розрахунки індексу маси тіла (IMT), тестування, методи математичної статистики.

Наукова новизна. Уперше науково обґрунтована та апробована авторська методика зниження надмірної маси тіла жінок другого періоду зрілого віку в умовах самостійних занять. Запропонована методика дає можливість здійснити індивідуальний підхід щодо дозування інтенсивності навантаження з урахуванням показників пульсу та віку. У методиці акцентована увага на корекцію рівня вісцерального жиру, а саме розміру 
окружності талії. Удосконалені знання щодо якості життя жінок зрілого віку, його залежності від індексу маси тіла та рівня фізичної підготовленості.

Виклад основного матеріалу. У дослідженні взяли участь 16 жінок віком від 56 до 60 років різних професій, переважно нервової напруги при незначному фізичному стомленні, одноманітних робочих рухах монотонного характеру, які виконуються сидячи. Усі досліджувані до експерименту займалися скандинавською ходьбою з палицями поодинці або в малих групах.

На початковому етапі констатувального експерименту було визначено індекс маси тіла (IMT) жінок другого періоду зрілого віку, запропонований Всесвітньою організацією охорони здоров'я. IMT розраховували шляхом ділення маси тіла (у кілограмах) на квадрат росту (у метрах квадратних). Індекс дозволив побічно оцінити, чи вага $є$ нормальною, надлишковою або особа має ступінь ожиріння. У результаті дослідження виявлено, що всі жінки мали надмірну масу тіла, на граничному рівні з ожирінням, у межах від 28,4

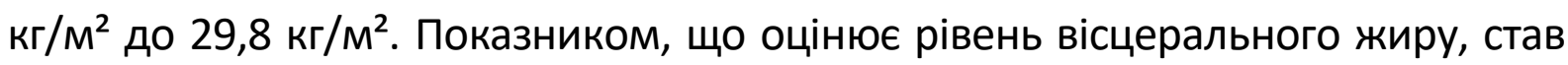
розмір окружності талії. Окружність талії в жінок була в межах від 80,5 см до 84,6 cм, що асоціювалося з підвищеним та високим ризиком небезпечних захворювань.

Для подальшого експерименту всіх досліджуваних було розподілено на контрольну (КГ) та експериментальну (ЕГ) групи, по вісім осіб у кожній, i встановлено, що між показниками IМТ статистично значимих відмінностей $(p>0,05)$ немає.

Досліджувані контрольної групи (КГ) займалися самостійно за загальноприйнятою методикою з використанням відео уроків та інших інформаційних ресурсів тричі на тиждень. Заняття складалося з трьох частин: підготовчої (20 хв.) - вправи на різні групи м'язів, дихальні вправи; основної частини (40 хв.) - ходьба з палицями з поступовим нарощуванням інтенсивності, ЧСС від 100 уд./хв. до 150-160 уд./хв. (залежно від самопочуття); заключної частини (20 хв.) - вправи на розтягнення м'язів і зв'язок та розслаблення, вправи на відновлення дихання.

Досліджувані експериментальної групи займалися скандинавською ходьбою за експериментальною методикою 3-4 заняття в тижневому мікро циклі по 1,2-1,5 години протягом шести місяців в умовах самостійних занять. Заняття проводилися таким чином, щоб не було перевантаження. Для цього нами використано «феномен обриву» (Фролькис, 1988), сутність якого полягала в тому, що досліджувані при високому ступені працездатності повинні були на деякий час припинити роботу, знизити показники пульсу, а 
потім знову їі продовжити. Це давало можливість запобігти глибокої втоми. Між тренувальними заняттями ми витримували не менше 48 годин. Заняття складалося з трьох частин: підготовчої - (15-20 хв.), основної - (40-80 хв.) і заключної (15-20 хв.). Всі заняття були розподілені на чотири етапи. Перший- тренування витривалості, яке здійснювалося за рахунок поступового нарощування часу занять (від 10 хвилин до 40-80) та інтенсивності з урахуванням чСС (14-160 уд./хв.), віку та самопочуття досліджуваних. На другому етапі, коли досліджувані звикли до навантажень і повноцінних занять, додали вправи на розвиток швидкості. Після того, коли домоглися потрібної швидкості пересування, перейшли до третього етапу інтервальних тренувань, які полягали в чергуванні ходьби швидкого та повільного темпу, використовуючи при цьому ходьбу по пересіченій місцевості. Кожна фаза інтервального тренування тривала 5-10 хвилин. При інтервальних тренуваннях ЧСС становила від 85 до 95 відсотків від максимального пульсу. Четвертий етап - вправи силового характеру, використовували різні обтяження з урахуванням індивідуальних особливостей. Після адаптації до навантаження заняття мали комплексний характер.

Результати показників індексу маси тіла в досліджуваних групах представлені в табл. 1.

Таблиця 1

Результати дослідження індексу маси тіла в жінок другого періоду зрілого віку до та після експерименту

\begin{tabular}{|c|c|c|c|}
\hline \multirow[b]{2}{*}{ Групи } & \multicolumn{2}{|c|}{ IMT } & \multirow[b]{2}{*}{ Достовірність } \\
\hline & $\begin{array}{c}\text { До експерименту } \\
\text { M } \pm m\end{array}$ & $\begin{array}{c}\text { Після експерименту } \\
\text { M } \pm m\end{array}$ & \\
\hline $\begin{array}{c}\text { Контрольна група } \\
\text { n=8 }\end{array}$ & $28,4 \pm 0,38$ & $28,1 \pm 0,36$ & \multirow[t]{2}{*}{$p>0,05$} \\
\hline $\begin{array}{c}\text { Експериментальна } \\
\text { група } \mathrm{n}=8\end{array}$ & $28,5 \pm 0,39$ & $25,1 \pm 0,34$ & \\
\hline
\end{tabular}

Фактичні дані в табл. 1 свідчать про те, що до експерименту між показниками IMT у контрольній та експериментальній групах статистично значимих відмінностей не було ( $>>0,05)$. Після введення розробленої нами методики відбулося зниження маси тіла за рахунок жирового компоненту

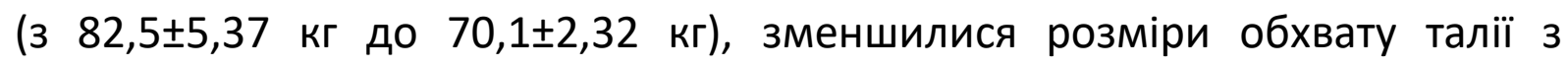

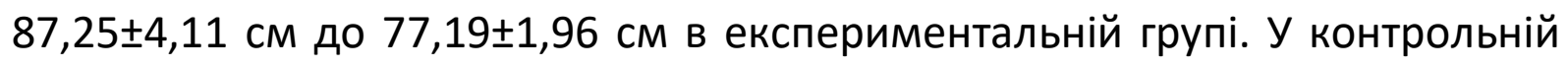
групі цей показник був дещо нижчий: зниження маси тіла було $з$

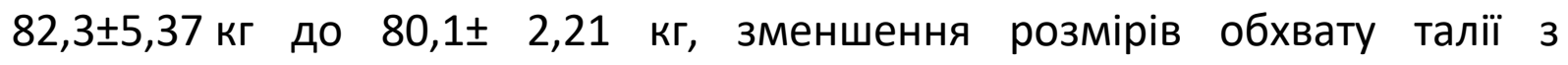
$87,41 \pm 3,12$ см до $82,19 \pm 2,96 \mathrm{~cm}$. 
3 метою визначення фізкультурно-оздоровчої дії експериментальної методики проводилося дослідження фізичної підготовленості. Для цього було використано систему КОНТРЕКС-2 (Душанин та ін., 1985), яка складається з одинадцяти показників (вік, маса тіла, артеріальний тиск, пульс у спокої, відновлюваність пульсу - медичні та рухові - гнучкість, швидкість, динамічна сила, швидкісна, швидкісно-силова та загальна витривалість) і має бальну систему оцінювання. Рівень фізичного стану визначали за сумою набраних балів, керуючись оціночною таблицею.

Вік досліджуваних відповідав кількості балів. Серед жінок ЕГ була одна досліджувана 56 років, три - 57, дві - 58 років, одна - 59 і одна - 60 років. У КГ була одна досліджувана віком 56 років, дві - 57, три - 58, по одній 59 та 60 років. Норма маси тіла оцінювалася за формулою, результати переводилися в бали. Так, у 100 \% досліджуваних ЕГ та КГ маса тіла перевищувала норму на 2-6 кг. 60 \% учасниць, які досліджувалися, мали вагу, яка перевищила норму понад 6 кг, вони не отримали жодного балу. Артеріальний тиск оцінювався у 30 балів, якщо відповідав нормі за формулою. Відповідно до досліджень, показники артеріального тиску відповідали нормі у 4 \% жінок, перевищували норму в межах 5 мм рт. ст. у $10 \%$ жінок (20 балів), у 86 \% жінок спостерігалися відхилення від норми в межах 25 мм рт. ст. і отримали по 5 балів. За кожен удар пульсу у спокої менше 90 уд./хв. нараховували 1 бал, таких виявилося 15 \%. У 54 \% пульс коливався в межах від 70 до 72 уд./хв., у 12 \% жінок пульс коливався в межах від 76 до 82 уд./хв., в останніх досліджуваних - у межах від 84 до 88 уд./хв.

Гнучкість оцінювали за допомогою нахилу вперед із положення стоячи на гімнастичній лаві. Показники гнучкості в ЕГ покращилися на 2,5 см і стали відповідати нормі, відповідно досліджувані отримали по 1 балу, за кожен 1 см більше норми - також було нараховано по одному балу. У КГ показники гнучкості були нижче за норму до та після експерименту, тому всі досліджувані отримали по 0 балів. Швидкість оцінювали за результатами швидкісного утримання сильнішою рукою лінійки, яка падає. Результати тестування засвідчили дуже низькі показники як в ЕГ, так і в КГ, до експерименту всі учасниці отримали по 0 балів. Після експерименту 48 \% жінок ЕГ зменшили норму на 1 см і отримали додатково по 2 бали. Динамічну силу оцінювали за результатами максимального стрибка вгору 3 місця. У результаті аналізу даних визначили, що в кінці експерименту 76 \% досліджуваних ЕГ виконали норматив і перевищили показники на 0,5 cм, отримавши при цьому по 2 бали. Швидкісна витривалість визначалася за кількістю піднятих ніг під прямим кутом із положення лежачи на спині 
протягом 20 с. Результати тестування показали, що до експерименту 100 \% жінок ЕГ та КГ не набрали жодного балу. Після експерименту $76 \%$ досліджуваних ЕГ виконали норматив і набрали по 3 бали, $12 \%$ перевищили норму і отримали ще по 3 бали. 18 \% жінок КГ після експерименту отримали по 3 бали. Швидкісно-силову витривалість оцінювали за виконання згинання і розгинання рук в упорі лежачи на колінах протягом 30 с. Це завдання видалося складним для обох груп. Лише після експерименту 24 \% досліджуваних ЕГ виконали норматив та отримали по 4 бали, ще 2 \% перевищили норму і за кожен см отримали додатково по 4 бали. Рівень розвитку загальної витривалості оцінювали за допомогою бігу на 1700 м. На початку експерименту із завданням не впоралася жодна з учасниць дослідження. I лише 4 \% жінок ЕГ на кінець експерименту вклалися в норму та отримали від 30 до 45 балів. Відновлюваність пульсу визначали, вимірюючи його в стані спокою, та після 20 глибоких присідань протягом 40 с через 2 хв. відпочинку за 10 с й отримане число множилося на 6 (результат переводили у хвилину). Аналіз даних засвідчив невисокі показники, оскільки відповідність пульсу початковій величині була наявна лише у $4 \%$ жінок. У 8 \% досліджуваних пульс перевищував початкову величину на 10 ударів і це відповідало 20 балам, $10 \%$ - отримали по 10 балів, ще $12 \%$ жінок - по 5, решта (66\%) досліджуваних не отримали жодного балу.

Таким чином, аналіз отриманих даних показав недостатній рівень фізичної підготовленості жінок обох груп на початку дослідження. Через пів року занять скандинавською ходьбою з палицями рівень фізичної підготовленості позитивно зрушився в жінок ЕГ. Так, низький рівень фізичної підготовленості в КГ на початку і в кінці експерименту мали 62,5 \%

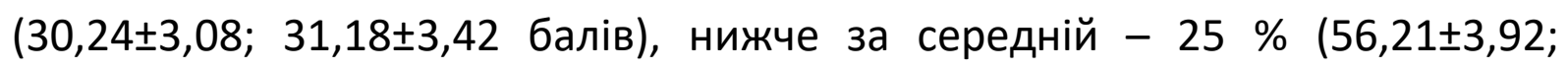

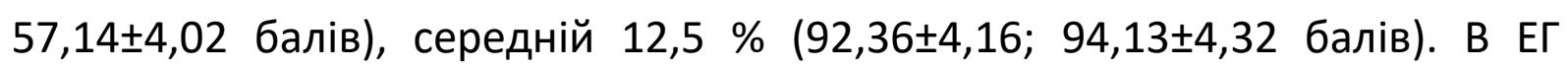
показники дещо різняться. Низький рівень фізичної підготовленості на

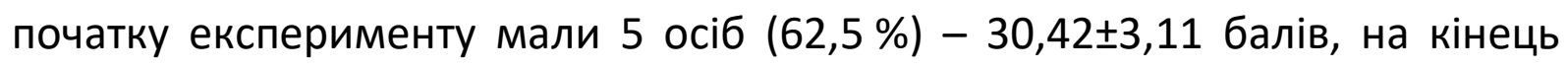
експерименту - 4 особи, це становить $50 \%(35,63 \pm 4,18)$. Кількість осіб, які мали нижче за середній рівень, не змінилася - $25 \%$ (57,22 23,46 ; $72,14 \pm 5,42)$. Середній рівень фізичної підготовленості на початку та в кінці експерименту мали по одній досліджуваній, що склало по $12,5 \%$ $(92,00 \pm 4,35 ; 122,17 \pm 4,45)$. В ЕГ на кінець експерименту вище за середній рівень фізичної підготовленості мала одна досліджувана, що становило 12,5 \% (162,14士0,6). Результати тестування представлені на рис. 1. 


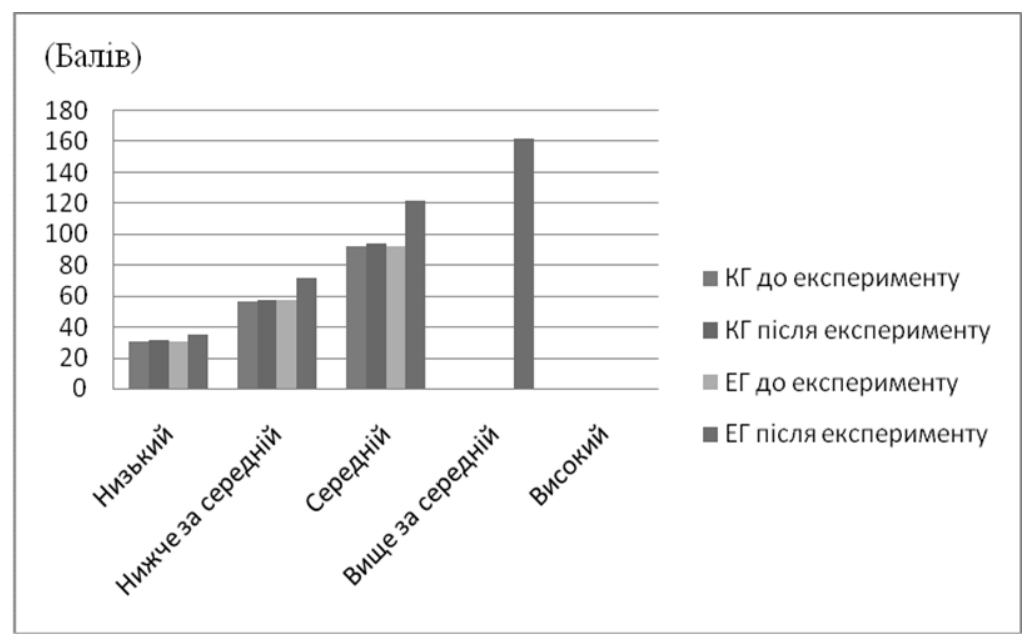

Рис. 1. Визначення рівня фізичної підготовленості експериментальної групи до та після експерименту

Одержані дані свідчать про те, що розроблена та реалізована експериментальна методика виявилася порівняно більш ефективною, ніж режим занять контрольної групи. Основним чинником досягнення позитивних результатів слід вважати врахування індивідуальних і морфофункціональних характеристик жіночого контингенту, що дозволило використовувати вправи на швидкість, інтервальної та силової спрямованості, раціональні за об'ємом і характером дії.

Висновки. У результаті аналізу літературних джерел було встановлено, що надмірна маса тіла $\epsilon$ однією з основних проблем жінок сучасності. Нагальним завданням стає пошук засобів схуднення та запобігання подальшого набору маси тіла. В експериментальній групі була досягнута позитивна динаміка зменшення маси тіла, об'єму талії, підвищення рівня фізичного стану. У результаті дослідження встановлено, що поєднане застосування аеробних, силових, швидкісних, інтервальних вправ, які $\epsilon$ складовими експериментальної методики, приводить до зниження маси тіла жінок другого періоду зрілого віку в умовах самостійних занять.

\section{ЛІТЕРАТУРA}

Душанин, С. А., Иващенко, Л. Я., Пирогова, Е. А. (1985). Тренировочные программы для здоровья. КОНТРЭКС-2. К.: Здоровья (Dushanin, S. A., Ivashchenko, L. Ya., Pirohov, Е. A. (1985). Health training programs. CONTREX-2. K.: Health).

Копылов, Ю. А. (2014). Скандинавская ходьба с палками. Физическая культура в школе, 6, 49-50 (Kopylov, Yu. A. (2014). Scandinavian walking with sticks. Physical Culture at School, 6, 49-50).

Мировая статистика здравоохранения 2014 г. (2014). Всемирная Организация здравоохранения. Женева, 21-24. У В. П. Огієнко, Статистичні дані по поширенню ожиріння в Україні і світі загалом. Режим доступу: http://medstat.gov.ua/ukr (World Health Statistics 2014 (2014). World Health Organization. Geneva, 21-24. In V. P. Ogienko, Statistical data on the distribution of obesity in Ukraine and the world as a whole. Retrieved from: http://medstat.gov.ua/ukr.). 
Павловская, О. И., Васянина, И. И. (2018). Обоснование разработки экспериментальной методики оздоровительных занятий скандинавской ходьбой для женщин старше 50 лет отнесенных к I и II группе здоровья. Наука и технологии: актуальне вопросы, достижения и инновации: сборник научных трудов по материалам XIV Международного междисциплинарного форума молодых ученых, 15 января 2018 2. Москва: Профессиональная наука, 125-129 (Pavlovskaia, O. I., Vasiana, I. I. (2018). The rationale for the development of an experimental method for health improvement by Nordic walking for women over 50 years belonging to the I and II group of health. Science and technology: topical issues, achievements and innovations: a collection of scientific works on the materials of the XIV International Interdisciplinary Forum of Young Scientists, January 15, 2018. Moscow: Professional Science, 125-129).

Рибалко, П. Ф., Козерук, Ю. В., Лисюк, С. М., Гончар, В.В.(2016). Теоретико-методичні основи організації самостійних занять фізичними вправами. Вісник Чернігівського начіонального педагогічного університету імені Т. Г. Шевченко. Серія: Педагогічні науки, 213-216 (Rybalko, P. F., Koseruk, Yu. V., Lysiuk, S. M., Honchar, V. V. (2016). Theoretical and methodological foundations of organization of independent physical exercises. Bulletin of Taras Shevchenko Chernigiv National Pedagogical University. Series: Pedagogical Sciences, 213-216).

Скандинавська ходьба як засіб рухової активності для студентів спеціальних медичних груп Д. О. Микиша (2013). Матеріали науково-теоретичної конференції викладачів, аспірантів, співробітників та студентів кафедри фізичного виховання і спорту: тези доповідей, м. Суми, 25 квітня 2013 р., 75-78. Суми: СумДУ (Nordic walking as a means of motor activity for students of special medical groups of D. O. Mykysh (2013). Materials of the scientific and theoretical conference of teachers, postgraduates, staff and students of the Department of Physical Education and Sports: Abstracts, Sumy, April 25, 2013, 75-78. Sumy: Sumy State University).

Чернов, С. С., Стрельцов, А. А. (2011). Дозированная ходьба и оздоровительный бег. Актуальные вопросы подготовки спортсменов в спорте высших достижений: материалы Всерос. Интернетконф. М., 189-193 (Chernov, S. S., Streltsov, A. A. (2011). Dosage walking and wellness jogging. Actual questions of preparation of athletes in sports of higher achievements: materials All Russia. Online Conf. M., 189-193).

Фролькис, В. В. (1988). Старение и увеличение продолжительности жизни. Л.: Наука (Frolkis, V. V. (1988). Aging and increasing life expectancy. L.: Science).

Футорний, С. М. (2015). Скандинавська ходьба - новий елемент формування здоров'я. Науковий часопис Національного педагогічного університету імені $М$. П. Драгоманова. Серія № 15. Науково-педагогічні проблеми фрізичної культури, 10 (65), 152-155 (Futorny, S. M. (2015). Scandinavia walking is a new element in the formation of health. Scientific journal of the National Pedagogical University named after M. P. Dragomanov. Series № 15. Scientific and pedagogical problems of physical culture, 10 (65), 152-155).

\section{PEЗЮME}

Прокопова Людмила, Гвоздецкая Светлана, Гриб Татьяна, Клименченко Татьяна. Скандинавская ходьба как средство снижения избыточной массы тела женщин второго периода половой зрелости в условиях самостоятельных занятий.

Изучено влияние скандинавской ходьбы на снижение избыточной массы тела женщин 56-60 лет. Определены изменения уровня фризического состояния женщин, которые занимаются скандинавской ходьбой. Разработана и экспериментально 
проверена методика снижения избыточной массы тела женщин второго периода зрелого возраста в условиях самостоятельных занятий.

Цель работы: обоснование и доказательство эфрфективности экспериментальной методики снижения избыточной массы тела женщин второго периода зрелого возраста в условиях самостоятельных занятий.

Методология. Методологическую основу исследования составляют принципы теории научного познания, концептуальные положения психологии, педагогики, медицины, в которых определены важнейшие принципы анализа социальнопсихологических и педагогических явлений, теория тренировочного процесса.

Научная новизна. Гипотеза исследования заключается в том, что совместное применение аэробных, силовых, скоростных, интервальных упражнений приведет к более выраженной коррекции фрорм тела у женщин второго периода зрелого возраста в условиях самостоятельных занятий.

Выводы. В результате анализа литературных источников было установлено, что избыточная масса тела является одной из основных проблем женщин современности. Насущной задачей становится поиск средств похудения и предотвращения дальнейшего набора массы тела. В экспериментальной группе была достигнута положительная динамика уменьщения массы тела, окружности талии, повышение уровня физического состояния. В результате исследования установлено, что совместное применение аэробных, силовых, скоростных, интервальных упражнений, которые являются составными экспериментальной методики, приводит к снижению массы тела женщин второго периода зрелого возраста в условиях самостоятельных занятий.

Ключевые слова: скандинавская ходьба, избыточная масса тела, физическое состояние, экспериментальная методика.

\section{SUMMARY}

Prokopova Lyudmila, Gvozdetska Svitlana, Hryb Tatiana, Klymenchenko Tatiana. Nordic walking as a means of reducing excess body weight of women in the second period of mature age in conditions of independent classes.

The influence of Nordic walking on reducing excess body weight of 56-60 year old women is studied. Changes in the level of physical condition of women engaged in Nordic walking are determined. The methodology of reducing excess body weight of women of the second period of mature age in conditions of independent classes has been developed and experimentally tested.

Purpose: to substantiate and prove the effectiveness of the experimental methodology of reducing excess body weight of women in the second period of mature age in conditions of independent classes.

Methodology. Methodological basis of the study are the principles of the theory of scientific cognition, conceptual provisions of psychology, pedagogy, medicine, in which the most important principles of the analysis of socio-psychological and pedagogical phenomena have been developed, the theory of the training process.

Scientific novelty. The hypothesis of the study is that combined application of aerobic, power, speed, interval exercises will lead to more vivid correction of body shape in women of the second period of mature age in conditions of independent classes.

Conclusions. As a result of the analysis of literary sources, it has been found out that overweight is one of the main problems of modern women. An urgent task is to search for weight loss and prevent further weight gain. The experimental group achieved positive dynamics of weight loss, waist circumference, and increased physical condition. As a result of the study, it has 
been found out that combined application of aerobic, power, speed, interval exercises, which are components of the experimental methodology, leads to a decrease in the body weight of women in the second period of mature age in conditions of independent classes.

Key words: Nordic walking, excess body weight, physical condition, experimental methodology.

УдК 378.046.4:004 (045)

\author{
Олександра Сологуб \\ Хмельницький обласний інститут \\ післядипломної педагогічної освіти \\ ORCID ID 0000-0003-4781-2973
}

DOI 10.24139/2312-5993/2019.05/256-268

\title{
ТЕХНОЛОГІЯ РОЗВИТКУ ІК-КОМПЕТЕНТНОСТІ МЕТОДИСТІВ РЕГІОНАЛЬНИХ СЛУЖБ У ПРОЦЕСІ ПІДВИЩЕННЯ КВАЛІФІКАЦІї
}

у статті розкрито структуру технології розвитку ІК-компетентності методистів міських (районних) методичних кабінетів (центрів), прачівників методичних служб об'єднаних територіальних громад у процесі підвищення кваліфрікації, виокремлено складники технології: концептуальний, цільовий, змістовий, процесуальний, оціночно-рефллексивний. Автор описує мету, обгрунтовує вибір підходів, принципів, змісту, форм, технічних засобів для реалізації технології, висвітлює психодізіологічні умови навчання дорослих слухачів, описує теоретичні та емпіричні методи дослідження, аналізує результати анкетування слухачів у ході експериментальної діяльності, планує подальшу роботу над дослідженням, спрямовану на коригування технології відповідно до результатів моніторингу.

Ключові слова: інформаційно-комунікаційна компетентність, методист регіональної служби, освітня технологія, технологія розвитку інформаційнокомунікаційної компетентності, дистанційні пролонговані тренінги.

Постановка проблеми. В умовах реалізації Концепції «Нова українська школа» важливо забезпечити процес розвитку інформаційно-комунікаційної компетентності методистів регіональних служб (методичних працівників міських (районних) методичних кабінетів (центрів), працівників методичних служб об'єднаних територіальних громад), які $\epsilon$ андрагогами, менеджерами професійного зростання педагогічних працівників. За результатами опитування, анкетування, спостереження констатуємо, що нерідко проблемою для методистів $\epsilon$ створення власних продуктів засобами інформаційно-комунікаційних технологій, організація співпраці та навчання у відкритих освітніх середовищах, фасилітація педагогів із питань використання цифрових технологій в освітньому процесі та ін.

3 метою створення умов для неперервного професійного та особистісного розвитку педагогічних працівників в умовах андрагогічного циклу на засадах випереджальності, адаптивності, відкритості освітнього процесу відповідно до сучасних вимог до організації навчання в закладах 